\title{
Antiplasmodial activity of Vernonia adoensis aqueous, methanol and chloroform leaf extracts against chloroquine sensitive strain of Plasmodium berghei in vivo in mice
}

\author{
Gebreyohannes Zemicheal and Yalemtsehay Mekonnen* ${ }^{*}$
}

\begin{abstract}
Objective: The aim of this study was to investigate the antiplasmodial effects of the crude aqueous, methanol and chloroform extracts of the leaves of Vernonia adoensis in Plasmodium berghei infected Swiss albino mice using Peters' 4-day suppressive test.

Results: The number of mice used for the toxicity test was 20 (5/group) and for each extract and control groups 5 mice per group was used. The aqueous, methanol and chloroform extracts of $V$. adoensis leaves indicated statistically significant $(P<0.05)$ suppression of parasitaemia in the treated mice. The highest inhibition was that of the methanol extract treated mice (83.36\%) followed by aqueous (72.26\%) and chloroform (54.34\%) at an oral dose of $600 \mathrm{mg} / \mathrm{kg}$ b.wt. Each extract prevented body weight loss and packed cell volume (PCV) reduction as compared to the negative control groups. The survival time of the mice treated with chloroform based on Kaplan-Meir analysis was $12.53 \pm 0.37$ at $600 \mathrm{mg} / \mathrm{kg}$ b.wt, while the negative control was $7.93 \pm 0.37$ days. The $L D_{50}$ of the extracts was greater than $3000 \mathrm{mg} / \mathrm{kg}$ body weight. In conclusion, the crude leaves extract of $\mathrm{V}$. adoensis have demonstrated antiplasmodial effect in vivo. P. berghei infection is suppressed in a dose-dependent manner showing relevance of the traditional use of the plant.
\end{abstract}

Keywords: Vernonia adoensis, Plasmodium berghei, Antiplasmodial, Parasitaemia, Chloroquine

\section{Introduction}

Malaria is still a public health problem in many parts of the tropics. Plasomodium falciparum and Plasomodium vivax are the most fatal species [1-5]. Currently quinine and artemisinin are the two effective drugs obtained from two traditional medicinal plants. Quinine was obtained from the bark of the Cinchona tree $[6,7]$ and artemisinin from the plant Artemisia annua [8,9]. However, in the recent years these drugs show some degree of resistance $[10,11]$.

Vernonia adoensis ( $V$. adoensis) is among the numerous traditionally used medicinal plants in Ethiopia. It is used

\footnotetext{
*Correspondence: yalemtshay.mekonnen@aau.edu.et Department of Biology, College of Natural and Computational Sciences, Addis Ababa University, P.O.Box 1176, Addis Ababa, Ethiopia
}

for malaria, gastro-intestinal complaints, muscle spasm and for healing wounds [12-15]. In Tanzania a rootinfusion is taken for stomach-pain and as anti-tuberculosis and fresh roots sliced and cooked is taken with milk against gonorrhoea [12]. Previously the antimicrobial [9], antioxidant and antipyretic [14] property of $V$. adoensis is reported.

In this study the antiplasmodial effect of the leaf crude extract of $V$. adoensis against chloroquine sensitive $P$. berghei in Swiss albino mice is tested.

\section{Main text \\ Plant material collection \\ Fresh leaves of $V$. adoensis were collected from Gondar town that grows freely around the Gondar Hospital, Ethiopia during the month of October, 2012. Field study}


and any plant material collection took place upon official authorization in accordance with country's laws and following international guidelines. The identification and authentication of the plant specimen was carried out by Professors Ensermu Kelbessa and Sebsebe Demissew at the National Herbarium of the Addis Ababa University (AAU). A voucher specimen number GZ 02/2012 of the plant sample was placed at the Herbarium.

\section{Preparation of crude plant extracts}

The preparation of crude extracts was done based on our previous published works $[16,17]$. In summary the collected plant leaves of $V$. adoensis were cleaned and air dried at room temperature under a shade in the Biomedical Science Laboratory of AAU. An electrical grinding mill (IEC, 158 VDE 0660, Germany) was used to grind the leaves. Sensitive digital weighing balance (AND: FX-320, Japan) was used to weigh the powdered plant material. Each extract was prepared in 1:10 ratio $(\mathrm{w} / \mathrm{v})$. Measurement of the percentage yield of each extract was done.

\section{Experimental animals}

We obtained the Swiss albino mice (25-34 g) from the Animal House of the College of Natural Sciences of AAU. Standard pellet diet and tap water ad libitum are fed to the mice housed in standard cages. All experiments were done three times and the tables represent the mean of the three experiments in each case. The Ethics Committee of the College of Natural Sciences of Addis Ababa University gave approval to run the experiment.

\section{Toxicity test}

Acute toxicity test (single dose exposure) of aqueous, methanol and chloroform extracts from the leaves of $V$. adoensis were evaluated in 3-h fasted Swiss albino mice through an oral administration of 2000, 2500 and $3000 \mathrm{mg} / \mathrm{kg}$ body weight of mice. The Organization for Economic Cooperation and Development (OECD) guidelines 425 procedure was followed to test the toxicity.

\section{Evaluation of the antiplasmodial activity}

In the in vivo evaluation of the antiplasmodial activity of the plant extracts was employed against chloroquine (CQ) sensitive $P$. berghei in mice using the standard 4-day suppressive method [18]. Gentle heart puncture from donor mouse and anesthetized with chloroform afforded $1 \mathrm{ml}$ blood the rising parasitaemia being about $33 \%$. Then, the $1 \mathrm{ml}$ blood was diluted with $4 \mathrm{ml}$ of physiological saline and thus, one ml blood contains about $5 \times 10^{7}$ infected red blood cells. The procedure we followed is previously given in Tekalegn et al. [16] and Zerihun et al. [17]. Twenty-five male mice were infected with $P$. berghei and randomly divided into five groups of five mice per group. Three test groups and two control groups $\left(\mathrm{dH}_{2} \mathrm{O}\right.$ or $3 \%$ Tween 80 as a negative control CQ as positive control). Each mouse was inoculated on day $0,\left(D_{0}\right)$ (intraperitoneally) with $0.2 \mathrm{ml}$ of infected blood having approximately $1 \times 10^{7} P$. berghei parasitized red blood cells as standard inoculum. The different doses given were $200 \mathrm{mg} / \mathrm{kg}$, $400 \mathrm{mg} / \mathrm{kg}$ and $600 \mathrm{mg} / \mathrm{kg}$ of body weight and $0.2 \mathrm{ml} \mathrm{CQ}$ at $25 \mathrm{mg} / \mathrm{kg}$. Standard intragastric tube was used to give the extracts and the controls. Treatment was started after $3 \mathrm{~h}$ of infection on $\mathrm{D}_{0}$ and then following four consecutive days in $24 \mathrm{~h}$ schedule.

On the 5th day Blood sample was collected from tail snip of each mouse on the 5th day. Thin smears preparation is as given previously $[16,17]$. The percentage parasitaemia and suppression was calculated as:

Percentage parasitaemia

$$
=\frac{\text { Number of parasitized red blood cells }}{\text { Total number of } \mathrm{RBC} \text { examined }}(\mathrm{RBC}) \times 100
$$

Percentage suppression

$$
\begin{gathered}
=\frac{\text { Parasitaemia in negative control }}{\text { Parasitaemia in negative control }} \\
- \text { Parasitaemia in treated } \times 100
\end{gathered}
$$

\section{Determination of body weight and packed cell volume} (PCV)

The body weight and PCV of each mouse in all the groups was recorded before infection and after infection. The average body weights were calculated as:

$$
\text { Mean body weight }=\frac{\text { Total weight of mice in a group }}{\text { Total number of mice in that group }}
$$

Heparinized microhematocrit capillary tubes up to 3/4th of their length was used to collect blood from tail of each mouse for PCV measurement. The tubes were sealed by crystal seal and placed in the microhematocrit centrifuge (Microheamatocrit Centrifuge, 583298, Hawksley \& Sons Ltd, England) with the sealed ends out wards. The sample was centrifuged at 12,000 rpm for $4 \mathrm{~min}$. The volume of the total blood and the volume of red blood cells were measured and PCV was calculated as:

$$
\begin{aligned}
& \text { PCV } \\
& =\frac{\text { Volume of erythrocytes in a given volume of blood }}{\text { Total blood volume }}
\end{aligned}
$$

\section{Determination of mean survival time}

Mortality was observed daily and the number of days from the time of inoculation of the parasite up to death was recorded for each mouse in the treatment and 
control groups throughout the follow up period. The mean survival time (MST) for each group was calculated using the SPSS version 20 applying Kaplan-Meir statistical analysis.

\section{Data analysis}

Results of the study were expressed as mean \pm standard error of the mean $(M \pm S E M)$. Data obtained from the parasitaemia, body weight, PCV and survival times were analyzed using Windows SPSS Version 15 . The one-way analysis of variance (ANOVA) and paired-samples Student's $t$ test were used to compare results among and within groups for differences between initial and final results. The result was considered statistically significant at $95 \%$ confidence level and P-value $<0.05$.

\section{Results}

\section{Toxicity test}

No death occurred in any of the groups and dose levels during the entire period of $24 \mathrm{~h}$ of observation. Furthermore, during the gross physical and behavioral observation of the experimental mice, for mice treated groups with the aqueous and methanol (99.5\%) extracts at the dose of $3000 \mathrm{mg} / \mathrm{kg}$ showed some reduction in feeding activity, hair erection and rigidity after the administration of the doses. In general, the oral administrations of the aqueous, methanol and chloroform extracts of $V$. adoensis in each doses of 2000, 2500 and $3000 \mathrm{mg} / \mathrm{kg}$ did not produce any significant changes in usual behavior and also no mortality. Therefore, the LD50 is greater than $3000 \mathrm{mg} / \mathrm{kg}$ body weight.

\section{Antiplasmodial activity}

The results of this study indicated that the in vivo aqueous, methanol and chloroform leaf extracts of $V$. adoensis exhibited a potent activity against $P$. berghei malaria parasite (Table 1). The Parasitaemia suppressive effects produced by all the test extracts were significant $(\mathrm{P}<0.05)$ as compared with their respective negative control groups. The highest percent suppression at $600 \mathrm{mg} / \mathrm{kg}$ body weight was $83.36 \%$. The mice treated with the standard drug (chloroquine $25 \mathrm{mg} / \mathrm{kg}$ ) were completely free from the parasites in all the experiments using the aqueous, methanol and chloroform leaf extracts of $V$. adoensis (Table 1).

\section{Body weight and packed cell volume (PCV)}

The plant extracts prevented body weight loss and the mean body weight on $\mathrm{D}_{0}$ and day $4\left(\mathrm{D}_{4}\right)$ did not show statistically significant difference $(\mathrm{P}>0.05)$ except at lower dose level of $200 \mathrm{mg} / \mathrm{kg}$ in both aqueous and chloroform extracts. Therefore, the prevention of body weight reduction by each extracts was dose dependent. Body weight
Table 1 Antiplasmodium activity of aqueous, methanol and chloroform extract of $V$. adoensis leaves against $P$. berghei in Swiss albino mice

\begin{tabular}{|c|c|c|c|}
\hline \multirow[t]{2}{*}{ Test extracts } & \multirow{2}{*}{$\begin{array}{l}\text { Dose } \\
\text { (mg/kg/ } \\
\text { day) }\end{array}$} & \multicolumn{2}{|c|}{ Antiplasmodial activity } \\
\hline & & $\begin{array}{l}\% \\
\text { Parasitaemia } \pm \text { SEM }\end{array}$ & $\begin{array}{l}\% \\
\text { Suppression } \pm \text { SEM }\end{array}$ \\
\hline \multirow[t]{4}{*}{ Aqueous } & NC & $25.79 \pm 1.00^{a}$ & $0.00^{\mathrm{a}}$ \\
\hline & 200 & $15.72 \pm 0.77^{b}$ & $39.04 \pm 2.99^{b}$ \\
\hline & 400 & $12.21 \pm 0.81^{b}$ & $52.62 \pm 3.16^{c}$ \\
\hline & 600 & $7.15 \pm 0.94^{c}$ & $72.26 \pm 3.67^{d}$ \\
\hline \multirow[t]{4}{*}{ Methanol } & NC & $21.23 \pm 0.49^{a}$ & $0.00^{\mathrm{a}}$ \\
\hline & 200 & $10.58 \pm 0.83^{b}$ & $50.17 \pm 3.91^{b}$ \\
\hline & 400 & $5.79 \pm 0.96^{c}$ & $72.71 \pm 4.52^{c}$ \\
\hline & 600 & $3.53 \pm 0.23^{c}$ & $83.36 \pm 1.12^{c}$ \\
\hline \multirow[t]{5}{*}{ Chloroform } & NC & $27.66 \pm 0.89^{\mathrm{a}}$ & $0.00^{\mathrm{a}}$ \\
\hline & 200 & $19.06 \pm 0.46^{b}$ & $31.09 \pm 1.66^{b}$ \\
\hline & 400 & $16.41 \pm 0.46^{c}$ & $40.65 \pm 1.60^{c}$ \\
\hline & 600 & $12.62 \pm 0.76^{d}$ & $54.34 \pm 2.78^{d}$ \\
\hline & $P C$ & $0.00^{e}$ & $100.00^{e}$ \\
\hline
\end{tabular}

Values are presented as Mean $\pm \mathrm{SEM}$

PC, positive control; NC, negative control ( $0.2 \mathrm{ml}$ of $3 \%$ Tween 80 )

$\mathrm{a}, \mathrm{b}, \mathrm{c}, \mathrm{d}, \mathrm{e}$ Values in the same column followed by the same letter do not differ significantly $(P>0.05)$

of the mice in the extract treated groups on $\mathrm{D}_{4}$ is significantly higher $(\mathrm{P}<0.05)$ than that of the mice in the negative control group (Table 2).

Table 3 shows that the test extract doses of $V$. adoensis prevented PCV reduction due to parasitaemia infection. Each result showed that $\mathrm{PCV}$ in the respective negative control groups were significantly $(\mathrm{P}<0.05)$ reduced in $\mathrm{D}_{4}$ while in the extracts treated groups significant change was not observed $(P>0.05)$. Furthermore, the analysis of variance performed between the extract treated groups in comparison with the corresponding negative control groups showed highly significant variation.

\section{Mean survival time}

All the experimental mice treated with the different extracts had increased dose dependent mean survival days (e.g. the chloroform extract exhibited the maximum MST of 12.53 at $600 \mathrm{mg} / \mathrm{kg}$ b.wt) as compared to the respective negative control groups (the maximum MST was 7.93). But all the mice treated with $C Q$ survived for 3 months (Additional file 1).

\section{Discussion}

All the test leaf extracts of aqueous, methanol and chloroform of $V$. adoensis have shown different degrees of parasitaemia inhibition in dose-related fashion. The highest suppression was recorded in the methanol extract 
Table 2 Effect of $V$. adoensis of aqueous, methanol and chloroform leaf extracts on the body weights of $P$. berghei infected mice

\begin{tabular}{|c|c|c|c|c|}
\hline \multirow[t]{2}{*}{ Test extracts } & \multirow[t]{2}{*}{ Dose (mg/kg/day) } & \multicolumn{2}{|l|}{ Body weight } & \multirow[t]{2}{*}{$\%$ Change } \\
\hline & & Before treatment $\left(D_{0}\right)$ & After treatment $\left(D_{4}\right)$ & \\
\hline \multirow[t]{5}{*}{ Aqueous } & NC & $28.22 \pm 0.42$ & $24.66 \pm 0.29^{*}$ & $-12.62^{\mathrm{a}}$ \\
\hline & 200 & $27.74 \pm 0.21$ & $25.66 \pm 0.52^{*}$ & $-7.49^{b}$ \\
\hline & 400 & $29.08 \pm 0.28$ & $28.88 \pm 0.71$ & $-0.68^{b}$ \\
\hline & 600 & $29.62 \pm 0.18$ & $28.46 \pm 0.49$ & $-3.92^{b}$ \\
\hline & PC & $29.66 \pm 0.38$ & $28.82 \pm 0.16$ & $-2.83^{b}$ \\
\hline \multirow[t]{5}{*}{ Methanol } & NC & $28.92 \pm 0.30$ & $25.82 \pm 0.09^{*}$ & $-10.72^{\mathrm{a}}$ \\
\hline & 200 & $30.60 \pm 0.31$ & $28.53 \pm 0.83$ & $-6.76^{b}$ \\
\hline & 400 & $30.08 \pm 0.34$ & $29.2 \pm 0.68$ & $-2.93^{b}$ \\
\hline & 600 & $28.5 \pm 0.36$ & $28.2 \pm 0.40$ & $-1.05^{b}$ \\
\hline & PC & $27.27 \pm 0.26$ & $27.12 \pm 0.24$ & $-0.55^{b}$ \\
\hline \multirow[t]{5}{*}{ Chloroform } & NC & $26.58 \pm 0.47$ & $22.72 \pm 0.27^{*}$ & $-14.52^{\mathrm{a}}$ \\
\hline & 200 & $51.67 \pm 0.25$ & $51.02 \pm 0.46$ & $-1.26^{b}$ \\
\hline & 400 & $52.3 \pm 0.36$ & $52.12 \pm 0.33$ & $-0.34^{b}$ \\
\hline & 600 & $53.16 \pm 0.63$ & $53.13 \pm 0.64$ & $-0.06^{b}$ \\
\hline & $P C$ & $51.42 \pm 0.35$ & $52.08 \pm 0.55$ & $1.28^{\mathrm{b}}$ \\
\hline
\end{tabular}

Values are presented as Mean \pm SEM

$\mathrm{NC}$, negative control ( $0.2 \mathrm{ml}$ of respective vehicle); $\mathrm{PC}$, positive control ( $0.2 \mathrm{ml}$ of $\mathrm{CQ})$

* There was significant change between $D_{0}$ and $D_{4}(P<0.05)$

$\mathrm{a}, \mathrm{b}$ Values in the same column followed by the same letter do not differ significantly $(P>0.05)$

Table 3 Effect of $V$. adoensis of aqueous, methanol and chloroform leaf extracts on the packed cell volume of $P$. berghei infected Swiss albino mice

\begin{tabular}{|c|c|c|c|c|}
\hline \multirow[t]{2}{*}{ Test extracts } & \multirow[t]{2}{*}{ Dose (mg/kg/day) } & \multicolumn{2}{|l|}{ Packed cell volume } & \multirow[t]{2}{*}{$\%$ Change } \\
\hline & & Before treatment $\left(D_{0}\right)$ & After treatment $\left(D_{4}\right)$ & \\
\hline \multirow[t]{5}{*}{ Aqueous } & NC & $51.13 \pm 0.62$ & $40.35 \pm 0.26^{*}$ & $-21.08^{\mathrm{a}}$ \\
\hline & 200 & $50.83 \pm 0.79$ & $50.31 \pm 0.93$ & $-1.02^{b}$ \\
\hline & 400 & $51.42 \pm 0.64$ & $50.68 \pm 0.63$ & $-1.44^{b}$ \\
\hline & 600 & $52.30 \pm 0.27$ & $51.93 \pm 0.36$ & $-0.71^{b}$ \\
\hline & PC & $53.06 \pm 0.60$ & $52.84 \pm 0.52$ & $-0.41^{b}$ \\
\hline \multirow[t]{5}{*}{ Methanol } & NC & $53.2 \pm 0.31$ & $43.28 \pm 0.85^{*}$ & $-18.65^{a}$ \\
\hline & 200 & $51.68 \pm 0.45$ & $50.81 \pm 0.46$ & $-1.68^{b}$ \\
\hline & 400 & $51.03 \pm 0.09$ & $50.29 \pm 0.49$ & $-1.45^{b}$ \\
\hline & 600 & $52.05 \pm 0.36$ & $51.38 \pm 0.27$ & $-1.29^{b}$ \\
\hline & PC & $50.78 \pm 0.39$ & $51.05 \pm 0.08$ & $0.53^{b}$ \\
\hline \multirow[t]{5}{*}{ Chloroform } & NC & $50.92 \pm 0.55$ & $44.01 \pm 1.53^{*}$ & $-13.57^{a}$ \\
\hline & 200 & $51.67 \pm 0.25$ & $51.02 \pm 0.46$ & $-1.26^{b}$ \\
\hline & 400 & $52.3 \pm 0.36$ & $52.12 \pm 0.33$ & $-0.34^{b}$ \\
\hline & 600 & $53.16 \pm 0.63$ & $53.13 \pm 0.64$ & $-0.06^{b}$ \\
\hline & PC & $51.42 \pm 0.35$ & $52.08 \pm 0.55$ & $1.28^{\mathrm{b}}$ \\
\hline
\end{tabular}

Values are presented as Mean \pm SEM

$\mathrm{PC}$, positive control; $\mathrm{NC}$, negative control $(0.2 \mathrm{ml}$ of $3 \%$ Tween 80$)$

$a, b$ Values in the same column followed by the same letter do not differ significantly $(P>0.05)$

Values shown by * are significant at $\mathrm{P}<0.05$ 
treated mice $(83.36 \%$ at the oral dose of $600 \mathrm{mg} / \mathrm{kg}$ ). Previous studies have demonstrated the presence of secondary metabolites such as alkaloids, steroids, saponins, flavonoides, anthraquinones, terpenoids, sterols, diterpenoid, glycosides, tannins and sesquiterpene lactones in Vernonia species [7, 19]. The parasitaemia inhibition could be attributed to the presence of these metabolites.

Furthermore, the present result is in agreement with the result of previous in vivo study by Abosi and Raseroka [20] that reported suppressive effect of ethanolic extracts from the leaves and root bark of Vernonia amygdalina, where the leaf extract at $500 \mathrm{mg} / \mathrm{kg}$ resulted in $67 \%$ suppression of parasitaemia while the root-bark extract exerted $53.5 \%$ suppression at the same dose.

Similarly, a study carried out by Melariri and co-workers [21] showed a marked growth inhibition of parasites with values of $85 \%$ and $95 \%$ by the combination of dichloromethane extracts of leaves of Cymbopogon citrates and $V$. amygdalina at dose levels of 400 and $600 \mathrm{mg} / \mathrm{kg}$ b.wt against chloroquine sensitive strains of $P$. berghei in mice respectively. $V$. amygdalina leaves dichloromethane extract alone exerted $95.8 \%$ parasitaemia suppression at a higher dose of $800 \mathrm{mg} / \mathrm{kg}$. In addition, the aqueous crude extract of the aerial part of $V$. ambigua had significant $(\mathrm{P}<0.05)$ parasitaemia inhibition in a dose dependent suppression of parasite growth [10].

The statistical multiple comparison of the effect of each extracts on the body weight and PCV among groups on the 5 th day of post-treatment and between $\mathrm{D}_{0}$ and $\mathrm{D}_{4}$ have shown that the two parameters to be within the normal range of values established for mice by Flecknell [15], adult body weight of $25-40 \mathrm{~g}$ and PCV of $32-54 \%$. Therefore, the absence of any significant differences in the body weight and PCV parameters provides a support for the safety (non-toxic) of $V$. adoensis at all doses administered to the experimental mice. Previous studies on different species of Vernonia that also includes the present work have justified the potential of this genus as an antiplasmodial agent.

In conclusion, the crude leaves extract of $V$. adoensis have demonstrated antiplasmodial effect in Swiss albino mice. P. berghei infection is suppressed in a dose-dependent manner. The traditional use of the plant has thus some relevance based on this study.

\section{Limitations}

The study was done only on the leaves of the plant and also only on crude extracts. It will be good if sub-fractions of the different extracts are tried. In addition using other parts of the plant such as the roots and flowers would have been more useful to come up with strong conclusion.

\section{Additional file}

Additional file 1. Kaplan-Meier analysis.

\section{Abbreviations}

AAU: Addis Ababa University; ANOVA: analysis of variance; b.wt: body weight; $\mathrm{CQ}$ : chloroquine; $\mathrm{D}_{0}$ : day zero; $\mathrm{D}_{4}$ : day four; $M S T$ : mean survival time; $M \pm S E M$ : mean plus/minus standard error of the mean; NC: negative control; PCV: packed cell volume; PC: positive control; RBC: red blood cells.

\section{Authors' contributions}

GZ wrote the research proposal, collected the plant material and did the experiment and drafted the manuscript. YM helped develop the research proposal and helped in analysis and interpretation of the results and in finalizing the manuscript. Both authors read and approved the final manuscript.

\section{Acknowledgements}

The authors thank the Addis Ababa University, School of Graduate Studies for financial support. Professors Ensermu Kelbessa and Sebsebe Demissew are thanked for identification and authentication of the plant material. Our thanks also go to Mrs. Amelework Eyado and Mrs. Tsige Yadessa their technical assistance in the laboratory.

\section{Competing interests}

The authors declare that they have no competing interests.

\section{Availability of data and materials}

The datasets used and/or analyzed during the current study are available from the corresponding author on reasonable request.

\section{Consent for publication}

Not applicable.

\section{Ethics approval and consent to participate}

The animal experiment was done upon approval by the Ethics Committee of the Department of Biology of the College of Natural Sciences, Addis Ababa University.

\section{Funding}

This work was funded by the School of Graduate Studies of the Addis Ababa University, Ethiopia. The funding was involved in approving the overall activity of the study.

\section{Publisher's Note}

Springer Nature remains neutral with regard to jurisdictional claims in published maps and institutional affiliations.

Received: 27 August 2018 Accepted: 9 October 2018

Published online: 17 October 2018

\footnotetext{
References

1. Ayele DG, Zewotir TT, Mwambi HG. Prevalence and risk factors of malaria in Ethiopia. Malaria J. 2012;11:1-9.

2. RBM progress and impact series. World Malaria Day: Africa Update, Roll Back Malaria. 2010.

3. Schlagenhauf P, Petersen E. Malaria chemoprophylaxis: strategies for risk groups. Clin Microbiol Rev. 2008;21:466-72.

4. WHO: Key facts about malaria. Geneva: World Health Organization; 2018.

5. Geleta G, Ketema T. Severe Malaria Associated with Plasmodium falciparum and P. vivax among Children in Pawe Hospital, Northwest Ethiopia. Malaria Research and Treatment, Hindawi Publishing Corporation. 2016. p. 1-7.
} 
6. Achan OA, Talisuna A, Erhart A, Yeka A, Tibenderana K, Baliraine N, Rosenthal J, Alessandro D. Quinine, an old anti-malarial drug in a modern world: role in the treatment of malaria. Malaria J. 2011:10:144-55.

7. Builders IM, Wannang NN, Ajoku AG, Builders FP, Orisadipe A, Aguiyi CJ. Evaluation of the antimalarial potential of Vernonia ambigua Kotschy and Peyr (Asteraceae). Int J Pharmacol. 2011;7:238-47.

8. Whegang Y, Tahar R, Foumane N, Soula G, Gwét H, Thalabard C, Basco K. Efficacy of non-artemisinin and artemisinin-based combination therapies for uncomplicated falciparum malaria in Cameroon. Malaria J. 2010;9:56-65.

9. Chitemere A, Mukanganyama S. In vitro antibacterial activity of selected medicinal plants from Zimbabwe. Afr J Plant Sci Biotechnol. 2011;5:1-7.

10. Dondorp AM, Nosten F, Yi P, Das D, Phyo AP, Tarning J. Artemisinin resistance in Plasmodium falciparum malaria. N Engl J Med. 2009;361(5):455-67.

11. Amato R, Lim P, Miotto O, Amaratunga C, Dek D. Genetic markers associated with dihydroartemisinin-piperaquine failure in Plasmodium falciparum malaria in Cambodia: a genotype-phenotype association study. Lancet Infect Dis. 2017;17(2):164-73.

12. Dalziel JM. The useful plants of West Tropical Africa. Being an appendix to the flora of West Tropical Africa. Crown Agents for the Colonies, London. 1955. p. 612.

13. Fowler G. Traditional fever remedies. A list of zambian plants. 2006.
14. Opoku R, Nethengwe F, Dludla P, Madida T, Shonhai A, Smith P, Singh M. Larvicidal, antipyretic and antiplasmodial activity of some zulu medicinal plants. Planta Med. 2011;77:1255-62.

15. Flecknell PA. Non-surgical experimental procedures. In: Tuffery A, editor. Laboratory animals: an introduction for new experimenters. New York: Wiley; 1987. p. 248-9.

16. Tekalign D, Mekonnen Y, Animut A. In Vivo Antimalarial Activities of Clerodendrum myricoides, Dodonea angustifolia and Aloe debrana Against Plasmodium berghei. Ethiop J Health Dev. 2010;24(1):25-9.

17. Zerihun TM, Petros B, Mekonnen Y. Evaluation of anti-plasmodial activity of crude and column fractions of extracts from Withania somnifera. Turk J Biol. 2013:37:147-50.

18. Peter W, Portus H, Robinson L. The four-day suppressive in vivo antimalarial test. Ann Trop Med Parasitol. 1975;69:155-71.

19. Ajayia E, Adelekeb T, Adewumia M, Adeyemia A. Antiplasmodial activities of ethanol extracts of Euphorbia hirta whole plant and Vernonia amygdalina leaves in Plasmodium berghei-infected mice. J Taibah Univ Sci. 2017:11:831-5.

20. Abosi AO, Raseroka BH. In vivo antimalarial activity of Vernonia amygdalina. Br J Biomed Sci. 2003:60:89-91.

21. Melariri P, Campbell W, Etusim P, Smith P. In vitro and in vivo antiplasmodial activities of extracts of Cymbopogon citratus staph and Vernonia amygdalina delile leaves. J Nat Prod. 2011;4:164-72.
Ready to submit your research? Choose BMC and benefit from:

- fast, convenient online submission

- thorough peer review by experienced researchers in your field

- rapid publication on acceptance

- support for research data, including large and complex data types

- gold Open Access which fosters wider collaboration and increased citations

- maximum visibility for your research: over 100M website views per year

At BMC, research is always in progress.

Learn more biomedcentral.com/submissions 